\author{
IS IT POSSIBLE TO UNDERSTAND THE \\ SYRIAN REVOLUTION THROUGH THE PRISM \\ OF SOCIAL MEDIA? \\ Juliette Harkin \\ University of East Anglia
}

Juliette Harkin, M.Phil Oxon, is a researcher and consultant on the Arab media and a PhD student undertaking research on Syria in the School of Political, Social and International Studies at the University of East Anglia. Her M.Phil thesis (2009) focused on the changing practice of journalism in Syria.

The aim of this article is to explore a renewed and radical 'media culture' that has developed in the extraordinary conditions of the Syrian revolution. The article quickly dismisses the focus on the technology and platforms while using small-scale ethnography to examine social networking sites like Facebook and to underscore the diversity of content being produced by Syrians. It notes how the Syrian media revolution is clearly well under way and how radical alternative forms of media production are flourishing.

\title{
KEYWORDS
}

media, radical alternative media, revolt, semi-published, social media, social networking sites, Syric

JULIETIE HARKIN: University of East Anglia 


\section{OF SOCIAL MEDIA?}

\section{Juliette Harkin}

University of East Anglia

The Arab revolutions have reminded the world that radical change can be effected by the people, rather than by top-down regime change or 'transitology' models that have prevailed in much academic literature (see critique in the Latin American context by Sparks, 2010). For Syrians irreversible transformations happened in the maelstrom of the revolt; they did not wait for the regime to fall or for discussion to commence about media reform blueprints.

The revolution has resulted in some important changes to the Syria media landscape. Research undertaken for this paper suggests that there has been a continuing growth in the use of social networking sites by Syrians (see Preston, 2011), with over 400 Facebook groups focused on Syria as of November 2011. Also, user-generated content produced by Syrians and disseminated on social networking sites such as Facebook and content-sharing plafforms such as YouTube have been major sources for international media outlets reporting on Syria (Harkin et al., 2012).

This high visibility and use of social media has served to foreground it in much analysis on the causes of the so-called Arab spring, including the Syrian revolt. But if the notion of a top-down transition to democracy seems out of step with the lessons of the 2011 Arab revolutions, it would also be foolhardy to suggest that isolating social media as a unit of analysis is possible or desirable in understanding the Syrian revolutions.

A few scholars are rightly employing a healthy scepticism and problematizing the idea of 'putting the internet central in our analysis' (Aouragh and Alexander, 2011; Lawson, 2011). Important too are critiques of the implicit or explicit neo-orientalist tendencies in the 'Facebook revolution' narrative (Burris, 2011). As David Gauntlett (1996) has pointed out, media researchers seeking to link cause and effect in society never managed to prove it.' Likewise, convincing evidence has not been forthcoming in the immediate studies into the role of social media in causing or amplifying the Arab uprisings (as exemplified by Dubai School of Government, 201 1a, 2011 b; Howard et al., 2011; Lotan et al., 2011).

Nevertheless, this article argues that if we situate the (social) media in their historical and political milieu, social networking sites can be one of a number of online and offline sources for researchers seeking to understand the Syrian uprising. This brief study is an exploration into examining content from social networking sites without making technologically determinist assumptions or, even more problematically, taking an Orientalist stance that Arabs could not possibly rise up against tyranny without the help of tools made in the USA.

In the form of a small-scale ethnography, as well as drawing on secondary material and informal interviews with media practitioners and Syrians outside their country, this article explores the changes in Syria's media ecology and the role of social media as a publishing platform and communication tool. In doing so the author acknowledges the limitations of drawing on material from social networking sites - necessitated in part by the difficulty of foreigners travelling to Syria but also by the dangers for Syrians inside the country to talk to 
foreign researchers. Some of the ethical dilemmas for researchers in conducting research on social networking sites are considered in the methodology section.

Alongside ethnographic research, this article draws on John Downing's (2001) work on radical alternative media and concludes that the revolt has nurtured some small-scale but important revolutionary media production which privileges people rather than elite power and rejects the dominant power structures of the state. As will be shown with examples in this article, the creative currents in the Syrian uprising and their survival strategies are evocative of Guy Debord's Situationists, who influenced the enragés' student occupation groups that emerged in 1968 (Viénet, 1968), ${ }^{2}$ in their utter rejection of the established order. In some small ways a state of anarchy does exist in Syria and the efforts of some Syrians to grow the 'intellectual culture' of their society is happening in the eye of the storm.

\section{Research Methodology}

Utilizing computer-mediated-communication (CMC) as defined by Hine (2010), mainly through the social networking site Facebook, but also through blogs, Twitter, contentsharing sites such as YouTube and websites, I observed how Syrians are producing rebellious 'cultural artifacts' offline and online (Durham and Kellner, 2006), and disseminating them via social media platforms. The research for this article was conducted through a small-scale 'virtual ethnography' and in doing so recognizes and concurs partly with Hine's assessment that such research might be 'necessarily partial and inauthentic because it only focuses on the online aspect' (Hine quoted in Kozinets, 2011: 5). I observed content posted on public Facebook pages during September to November 2011; content surveyed was random and not a representative sample. This tentative exploration served rather to gain insight into the kind of content being posted on social networks in relation to the uprising. This limited study could be developed further drawing on the research methodology set out by Kozinets, who convincingly argues that online ethnography which follows a 'specified, distinct, common set of methodological procedures and protocols that have been agreed upon by a community of scholars' should be regarded as a particular practice which he terms 'netnography' (2011: 60-1).

More research on Syria needs to be done to pursue some of the questions raised in this article; this would necessarily encompass field ethnography that would engage face-to-face with Syrians using the internet to disseminate information (as in Aouragh's extensive and detailed online and offline research for Palestine Online, 201 la). So, it is important not to over-interpret the observations made in this study but rather to use them to point to possible further avenues of research.

Despite the limitations set out above, Facebook is being used on a number of levels and it is useful to outline some developments here. Social media sites have been a platform for contestation between Syrians with opposing and differing political positions on the revolt. Discussions, far removed from a Habermasian ideal on many levels, are reflected through status updates, extensive comment strands posted on walls and notes shared by friends in the network. ${ }^{3}$ I had originally wanted to communicate with journalists and writers inside Syria, via my own established online social networks, to discuss their 'semi-published' (see below, Bruckman quoted in Kozinets, 2011: 145) discussions on the pages of Facebook and to seek their 'informed consent' (Rutter and Smith, 2010) to use this material. Ethically I felt it was not the right time to be contacting Syrians inside the country to conduct academic research, not least because I was unsure of how safe communications would be (see York, 2011), during the period of my online research, so I necessarily had to shift my research focus.

The dilemma of privacy is nicely illustrated in relation to an exchange between the prominent political commentator Asad Abu Khalil and Syrian dissident Yasin Haj Saleh In articles published in a left-leaning Lebanese newspaper, Yassin admonished Asad for quoting his private status update from Facebook in his article. ${ }^{4}$ Facebook has become a site of intense political debate, as opposed to a social chat site (MacManus, 2011; Salem, 2011) and so there are rich pickings but real ethical and security concerns too (as well as challenges for virtual archive research). In the age of the internet, this grey zone which Bruckman (quoted in Kozinets, 2011: 145) termed 'semi-published' has made binary distinctions between published and unpublished 'obsolete'. As well as the research ethics there are also the considerations of corporate policies on privacy; Facebook's stated privacy policy is that those wishing to take content from their friend's pages must approach them, explain what they want to do and then get express permission to use friends' content on Facebook before they disseminate it to the wider public (this was before Facebook introduced more open functions in September 2011, which offered users the option to have public subscriptions).

The second level at which Syrians have actively been using Facebook, and the focus of this article, is the very publicly listed groups and publications that appear to have mushroomed as a result of the intensifying repression of public demonstrations and civil disobedience in Syria during 2011. The social networking sites on Syria looked at here provide merely one small way to gain information on changes to Syria's information ecology, given that the Syrian community in and outside of Syria is using it as a communication and media tool.

I highlight here some of the most popular Facebook pages, measured by the number of people who have liked them (members) and how active the comments section of the wall has been when I accessed these sites during September and November 2011. All these pages are set up as 'public' and anyone can 'like' them. With certain caveats (no citation of individuals), researchers can treat this content as 'published'. ${ }^{5}$ As with the established media, it can be assumed that social media platforms and content might also suffer from an elite bias, reach only a tiny amount of the population, and 
present only one or a small number of the possible narratives for how Syrians are living through the uprising. Additionally, in the case of the internet and Syria, there is little easily available data on who is using the social networking sites and from where - so many of the groups discussed here might be populated with conversation strands and the views of expatriates, exiles or refugees - this smallness of scale and geographical diversity does not detract from the significance of the content and I argue that it is reflective of revolutionary changes for the Syrian media landscape.

\section{The Syrian Revolt and Media, in Context}

To properly situate Syria's media, in the context of the 2011 uprising, it is useful to think about the media landscape in historical context. Some of the writings of the revolution evoke Syria's political and cultural history and yearn for the perceived expressiveness and political activity that preceded the Ba'ath regime. Syrians remember a lost sense of citizenship, as detailed in Amal Hanano's (2011) series on Syria's former leaders and in Mohammed Atassi's (2011) opinion piece in the New York Times. Numerous articles have detailed the activism of Syrians inside and outside their country (Abu-Assali, 2011; Allaf, 2011; Marrouch, 2011; Zeitouneh, 2011b).

Despite some notable periods of increased freedom for the press since the Syrians achieved independence in 1946 (Provence, 2005: 24-5), the Syrian media has mainly been characterized by its state control and the advent of a 'hybrid' private media Harkin, 2009) established under Bashar al-Asad. As with business and political elite networks (documented by Haddad, 2012; Heydermann, 2004; Perthes, 2004), media owners and elites are also tied into the political structures and obtain economic and political benefits, including licences to operate and distribute their publications, favourable advertising deals and more freedoms, because of their connections to prominent members of the government, army or security (Kawakibi, 2010). Nominally 'private' publications have become mouthpieces for the regime during the revolt and newspapers like al-Watan have been burnt by demonstrators in YouTube video clips, ${ }^{6}$ others, like the web news site www.syria-news.com, have been at pains to try to represent the views of the demonstrators as well as the regime - a dangerous task for journalists working inside Syria and, some might argue, a futile one.

Studies of Syrian cultural production have sought to understand the human relations involved in the 'negotiations' between the state and cultural producers (Dick, 2006, 2007; Harkin, 2009). Research has indicated that state-led changes can have some positive unintended consequences, as well as the more negative aspects of selfcensorship and compromises necessary to maintain operations (Harkin, 2009). The regime's decision to allow internet news sites to operate, mostly focusing on the economy, allowed new kinds of journalistic practices for internet news sites - such as writing original copy rather than taking it from news agencies, having on-the-ground reporters doing local stories from all the provinces, and encouraging less bureaucratic editorial and management processes (Harkin, 2009). But these changes did not herald any real political or media freedoms. Commentary on Syrian Ramadan dramas has raised important issues around the negotiation of freedoms and the chances for boundaries to be pushed in ways that might be irreversible (Dick, 2006). Generally, the argument boils down to the extent to which people might subvert or seek to challenge or change the system from within (Kawakibi [2010] sets out the structural confines for private media).

In other analyses of Syrian cultural production, relative freedoms have been seen merely as instances in which the regime is allowing tanfiseh (letting air out, or letting off steam), as problematized by Wedeen (1999) and Cooke (2007). Both Wedeen and Cooke recommend caution about 'licensed criticism' and 'commissioned criticism' as only serving to create a 'democratic façade'. These arguments do not account for unintended outcomes and neither do they give enough room to the role of human agency; in any case, such arguments have been superseded by the Arab revolutions of 2011 , including Syria's, in which the role of human agency and a person's potential to 'act otherwise' (Pleasants, 1997) is firmly back in the picture.'

The Syrian state's strategy of placing very severe restrictions on foreign media and persisting in a brutally repressive crackdown certainly has had some unintended consequences. In Syria, while the old propaganda machines of the state were increasingly creative in spreading misinformation (an early example being the statesupported Duniya TV claim that Al-Jazeera Arabic had built a Syrian film set in Qatar so it could fabricate videos of protests), ${ }^{8}$ new forms of media took shape. In the context of the uprising we now need to look at more radical models for media and communications in times of change. We can see similar intellectual struggles at play in Egypt in its revolutionary phase, where counter-hegemonic media outlets have been launched, for example the web television service 25TV and Tahrir newspaper.

\section{Syria Online}

Syrians have had access to the internet since 1997 but this was only extended to the general public in 2002 (Eid, 2004). By 2004 there were approximately 500 internet cafes in Syria and all these small-scale internet access points were monitored by the Syrian authorities (Eid, 2004). There are two licensed ISPs (internet service providers) in Syria, both controlled by the government, or by those with close family ties to those with power, such as Rami Makhlouf (Ismail, 2009), who owns Syriatel and has the monopoly on telecommunications in Syria. In terms of access to PCs at home, estimates in 2004 put the number of PCs in Syria at 300,000, mainly owned by the organs of state (Eid, 2004). 
The Arab world has seen a significant growth in the signing up to and use of social networking sites. In 2010 the most common use of the internet was to access email, closely followed by logging on to Facebook (SpołOn PR/Effective Measure, 2010). A report by the Dubai School of Government (201 la) tracked Facebook penetration in the Arab world 9 using Facebook's official data. It showed there had been 78 percent growth from 11.97 million in January 2010 to 21.36 million in December 2010 (201 la: 4) and by June 2011 there were nearly 30 million Facebook users in the Middle East..$^{10}$

Because of the 2004 US technology sanctions ${ }^{11}$ on Syria (which pre-date the 2011 sanctions and have since been part rescinded to allow certain technology inflows), figures from Facebook's advertising arm are not available for Syria. For its 2010 figures, the Dubai School of Government works to an estimate of 241,859 Facebook users in Syria, based on undefined internet sources. That would be a 1 percent penetration in 2010, compared to just over 23 percent in Lebanon in the same year. It could be argued that Facebook penetration in Syria is now significantly higher than this figure. First, Syria follows the regional trend, which has witnessed huge growth in the number of people using social networking sites and a youth demographic which has an affinity for social networking sites like Facebook. Second, the Syrian regime liffed a formal ban on Facebook on 8 February 2011 (this was not to allow more freedoms but to make social media easier to monitor - the common practice in Syria of using proxies o access banned sites hindered government monitoring). Nevertheless, perhaps knowing that the ban was formally liffed encouraged new users of Facebook and other social media in Syria. Indeed the Dubai School of Government May 2011 report shows a significant spike in YouTube (as Facebook data is not available) use from Syria soon after the ban was lifted (2011b: 2). Also, as a result of the Syrian government's decision to shut down broadband in Syria, users resort to dial-up facilities and there is also a growing use of $3 \mathrm{G}$ mobile technology, where it is accessible (Kassab and Lane, 2011). Where it is not accessible some activists have used satellite phones (such as Thuraya). In summary, it seems clear there have been marked increases in the use of social media sites in Syria after February 2011,12 but that access is uneven inside Syria, suggesting an urban bias.

A search, in Arabic text, on 10 November for 'Syria' groups on Facebook revealed over 400 'pages' or groups dedicated to the political, cultural, academic and leisure spheres. Further observation of the Facebook sites that are engaging on the topic of the Syrian revolt revealed that the social network is a growing source for Syrians inside and outside their countries. Views represented range from the pro-regime sites liked by over 1000 users such as We Are All Shabiha' ${ }^{13}$ to sites set up by anti-regime groups including We Are All the Child Martyr Hamza Ali al-Khatib ${ }^{14}$ which had over 362,000 likes at the end of 2011 and by August 2012 had over 570,000 likes. I will elaborate on some of these virtual groups in the remainder of this article.

\section{Syria's Media and Information Ecology}

In seeking to understand how people attempt to circumvent hegemonic discourses to get radical and alternative information out, this article draws on the work on radical alternative media undertaken by John Downing (2001). In seeking to define exactly what radical media is, Downing offers a typology that sets the radical alternative media apart from mainstream, dominant media forms. Radical alternative media all share one thing in common: 'they break someone's rules' (2001: ix). This might be operationalized by expressing opposition vertically from subordinate quarters directly against the power structure and its behaviour, as well as building support solidarity and networking laterally against policies, or even against the very survival of the power structure. Importantly, Downing notes that radical alternative media is often small-scale underfunded and unnoticed, ridiculed or feared (or both) and might be short-lived or last for decades. Key to an understanding of such forms of media is the necessity not to look at and judge in a given moment but to consider it in the 'slow burn' of time (Downing, 2001: 6)

While it is too early to make pronouncements on Syria's growing radical media sphere, it does pose the question as to whether the Syrian use of social media during the uprising might fit Downing's conception of a radical alternative media. In itself Facebook, as a commercially supported platform, is not radical and alternative at all. But context, as well as consequences are important to Downing, and perhaps help in avoiding the trap of falling into a binary separation of mainstream or radical. As can be seen in this article, in the review of the Syrian media, context can take a seemingly benign action and transform it into a radical departure from the (enforced) norms in society. With questions about form and meanings for radical alternative media in mind, this article will now make some observations about the ways in which Syrians are using social media platforms to communicate, network, debate ideas and publish information.

A vibrant albeit small-scale production of weekly newspapers, published via blogs, Facebook groups, as well as in print form, has been a significant development during the Syrian revolt that started in March 2011. Publications such as Hurriyat, ${ }^{15}$ which was established in August 2011 and edited by a Syrian living in Europe, are effectively tapping into the ideas and actions of the demonstrators and activists. Of course the newspapers reflect differing political positions, with some leaning more towards what has been grouped as the 'internal' Syrian opposition and others that have a clear agenda which supports opposition groupings such as the Syrian National Council. The content is mainly in Arabic and the newspapers seem to have genuinely local content from their activist contacts around Syria. Hurriyat's Europe-based editor-inchief, Kareem Lailah (he uses a pseudonym), indicates the mobilizing nature of the publication in an interview with France24, in which footage was shown of newspapers 
being delivered anonymously to Syrian residents - trying to reach out to the 'silent majority'. ${ }^{16}$ Other newspapers have joined Hurriyat, including al-Haq (The Truth) in postings on YouTube and Facebook, as well as a website that has been established or al-Badeel (The Alternative). ${ }^{17}$ On 26 September 2011 Souriatna (Our Syria), a weekly newspaper, was launched and available in multiple formats for download via a Wordpress blog and on its Facebook page. ${ }^{18}$ The site announced that it was in the service of the revolution and that it was produced by the Free Syrian Youth. Its front cover hosted a colour picture of shahid (martyr) Ghaith Matar and a poem dedicated to his memory. Ghaith was a very visible signifier of the values of the peaceful protest movement - he was known for handing soldiers flowers and urging his fellow demonstrators to ensure the protests stayed peaceful. Each week Souriatna dedicates a column to an historical figure from Syrian history. These have included Khalil Mardam Bey (1895-1959), Sa'ad Allah al-Jabri (1891-1948), Hashim al-Atassi (1875-1960) and Adeeb al-Shishikli (1909-64). Souriatna also publishes updated figures for civilian deaths city by city, commentary on the wider Arab spring, revolutionary and anti-Asad graffiti in Syrian cities, commentary by established human rights activists such as Razan Zeitouneh (e.g. Zeitouneh, $2011 \mathrm{la}$ ) and views about the external opposition meetings taking place regarding the formation of the Syrian National Council.

These new e-magazines and social media groups are meeting a latent need for Syrians to be able to publish their narrative on the revolt, as well as the practical sharing and dissemination of information. The limited - in terms of access to the internet and security considerations - social media context in which I am reviewing published and semi-published information suggests that we are seeing only a small part of an ever-changing and dynamic process. New groups and initiatives are constantly emerging, such as the new Syrian Writers Association, ${ }^{19}$ announced in January 2012, followed by the announcement of a new independent journalists association.

There has also been the formulation of alternative news sources from Syria, which have become more organized over the course of the revolt and have become a main source for the international media covering Syria, mainly from afar. Chief among the various groups is the Sham News Network, which has its own YouTube channel as well as Facebook group. ${ }^{20}$ With nearly 200,000 Facebook followers by November 2011, it remains a major source for the Arab satellite channels (its logo can be seen regularly on air) and many other international media outlets. It was joined by a now equally ubiquitous news source in the form of a news agency called Ugarit, ${ }^{21}$ providing footage from within Syria.

Another leading Facebook group, now a highly organized activist and political network that also launched a humanitarian fund in December 2011, is the Syrian Local Coordinators Committee (LCC) 22 - with around 14,300 likes in November 2011. This site posts daily YouTube videos of demonstrations from around Syria, information on martyrs and figures for those killed, injured, kidnapped, tortured or arrested across Syria. There are also committee and media groups on Facebook for all the major towns which have been the most active in the revolt, including Hama, Idlib, $\mathrm{Homs}^{23}$ and Dera'a. ${ }^{24}$ This committee system is reminiscent of the writings of Hannah Arendt's On Revolution (2006 [1963]).

However, there have been concerns about the veracity of the information posted at different times. One of the activists involved in posting content from sources around Syria has been based in Beirut, in hiding. Omar Edelbi was interviewed for al-Akhbar newspaper in Lebanon and explained how he had fled from Homs but continued to keep in touch with a network of activists to get content straight from the demonstrations. Edelbi said he refused to post any footage of protesters calling for international military intervention as this was not in the interest of the revolution (Marrouch, 2011). So it should be noted that, not surprisingly, activist communication is not necessarily benign or without an agenda. Edelbi is now a member of the Syrian National Council, which represents particular positions of some parts of the Syrian political opposition. Some Syrians interviewed during the writing of this article also say that the Sham News Network is influenced by Islamist and Salafi currents. While it is difficult to see how a loose network of activists can be labelled as 'slamists' it is clear that some caution is required in dealing with user-generated content. Because of the situation in Syria there are ethical considerations in contacting committees/activists for academic research purposes to discuss these issues in more detail (the risk of exposure for the Syrians, the time constraints and need for activists to prioritize getting information into the mainstream media rather than an academic journal), but if the conditions were right it would be a rich research project.

Political alignments in communication and media are to be expected, but the new sense of plurality and an attendant idealism is to be welcomed in any case. On 9 November, the Facebook site Liberal Intellectuals for a Free Syria posted an article by Samera Tayara (2011) entitled 'Optimistic'. In it she describes how she is now 'free'. The revolt is not only against an authoritarian system, but also a rejection of the notion of the Arab state as a body worth mediating with at all. In small ways Syrians are 'acting otherwise'(Pleasants, 1997);25 for example, by placing recordings of revolution singer Ibrahim Qashoush, the martyr whose throat was hacked open before his dead body was dumped in Hama, in dustbins blaring out his song ${ }^{26}$ in Damascus' souqs and thoroughfares. Syrian citizens communicate their messages to Syria's 'silent majority'. ${ }^{27}$ On 5 October 2011 Syrian activists filmed a fountain coloured with red dye to represent the Syrians murdered by the security forces and army; the activists were in a car driving around the roundabout at close range to film, at great personal risk. The footage was posted on the Facebook page of the Coordinators for the Syrian Revolution in the District of Midan (Damascus). ${ }^{28}$ Other acts of defiance have included 
hoisting Syria's historic independence flag (see programme on Al-Jazeera, ${ }^{29}$ in Arabic, for the significance of the flag) on major buildings such as universities, or releasing balloon ${ }^{30}$ in a Damascus suburb, Kafar Souseh, and the commercial capital of Aleppo and Idlib. ${ }^{31}$ Activists have filmed the dangerous delivery of revolutionary newspapers in Syria. ${ }^{32}$ All these expressions are representative of 'cultural artifacts' (Durham and Kellner, 2006) that present at once a reconnection with a pre-Ba'ath revolutionary past (Provence, 2005) and a return to civil disobedience and dissent, as evidenced by the calls for strikes that have taken place in some towns and cities. ${ }^{33}$

Leading Syrian intellectuals, such as Burhan Ghalioun and Suheir Atassi, can be followed on Facebook's new subscriber pages and Syria's other ageing but respected dissidents, such as Michel Kilo and Hussein Odat, have 'semi-published' social networks on Facebook, sharing publications, information and views within their own social networks and on some of the sites mentioned in this paper. The Syrian Library ${ }^{34}$ is another example of this renewed flurry of intellectual discourse. With over 2000 members, it is a pro-revolution site that gives links to pertinent information, such as a 2010 book for download on Bashar's Syria, by long-time dissident Yassin al-Haj Saleh, as well as day-to-day commentary by Syrians such as Rosa Yassin Hassan, Faras Atassi, Hisham al-Hamawy and Ala Malas (some writers are using an alias), as well as Lebanese writer Elias Khouri and the editor of al-Quds al-Arabi newspaper, published from London, Abdel Bari Atwan.

Alongside established names, who get coverage in the international media, are less well-known views from human rights activists, liberal intellectuals, students and other segments of the uprising inside Syria. The Facebook group for Liberal Intellectuals for a Free Syria ${ }^{35}$ carries detailed expositions of, for example, visions of a more equitable society, as written by Anwar al-Bunni, president of the Syrian Centre for Legal Studies and Research. It is worth noting that al-Bunni, a lawyer who represented the Damascus Declaration signatories in court, was writing from inside Syria, as are many others who publish via social networks.

In a similar vein, the Syrian Intellectuals and the Voice of Syrian Thinkers ${ }^{36}$ Facebook group had over $\mathbf{7 7 0 0}$ members during the period of research and re-publishes articles calling for support of revolutionary causes, such as the resumption of a trial of Syrian intellectuals who were arrested on 13 July 2011 for demonstrating without a permit from the Ministry of the Interior. This group included well-known intellectuals and elites such as film-maker Nidal Hussan (since kidnapped and then released in December 2011) and actress May Skaf (arrested and released at time of writing).

This article has set out to illuminate the smaller-scale cultural production by activists and demonstrators who have recorded and disseminated history, as well as taken part in it. These patterns of 'media culture' (Durham and Kellner, 2006) are forming in reaction to the existing media structures, which is now not only a means of propaganda but also nurtures rumour as a 'means of control' (Sharabajee, 2011). The deepening repression of the Syrian regime (Human Rights Watch, 2011; United Nations General Assembly, 2011) has highlighted how a diverse resistance, from farmers to doctors and young students (see Al-Zu bi, 2011) are creating what Downing (2001) describes as 'radical alternative' media; people seeking ways to disseminate information under the extraordinary conditions that prevail in Syria.

Although Syria may lack the more established activist structures that had been well established in Egypt prior to its revolution (Beinin, 2001; Pratt, 2007), my research suggests a resolutely growing engagement and organization in Syria of new activist committees, intellectual and political groupings and protest movements, as well as pro-regime ${ }^{37}$ social media activity. Syrians are taking advantage of the uncertain environment to create counter-hegemonic intellectual and activist currents online (Barney and Grimes, 1997) and offline.

\section{Conclusion}

The notion of revolutionary communications during Syria's 2011 revolt opens a connection with its history of revolt against colonial rule. More research is needed on how demonstrators and civilians in isolated Syrian towns and cities are communicating and sharing information. This will of course be difficult to do in the foreseeable future. It would be interesting to compare what happened in 2011 with past revolutionary forms of disseminating information. We can see examples from history re-emerging in today's Syria.

In looking at forms of 'media culture' it seems we need to expand our conceptions of media, from its narrow sense of broadcast and print media, to include radical and diverse forms of cultural production and information dissemination. Certainly the kind of grassroots cultural production that has been explored in this study requires us to think about how we understand radical and revolutionary media forms. This might help us to get a clearer picture of the potential for where Syrian 'media' might be heading.

The danger is that, when populations revolt and topple authoritarian regimes, resort to neoliberal and liberal media models will crush any hope of a truly free and unfettered media culture, thus stunting the growth of the people's revolution.

The Arab world has had a wholly negative experience of a media that has been situated within or controlled by the state structures. The revolt has required activists to seek alternatives to this under the most extreme conditions. Under the brutality of the regime fight-back there has been an ironic renaissance of cultural, artistic and political trends that might eventually agitate against the imposition of a 'media system', either from within or from without. 
The author acknowledges Henry Allen for pointing out Gauntlett's work on media and effects.

2.

I am grateful to Nuno Coelho for discussions about the Situationist International.

3.

Both pro-regime and revolutionary social networking sites users have stoked some vitriolic and, in some cases, dangerously sectarian discussion strands on Facebook groups. See for example a posting which lists the names of doctors accused of killing protesters admitted into hospital in Homs, together with the comments strand. See: https://www.facebook.com/photo. php?fbid $=10150588031215727 \&$ set $=t .905090$ 606\&type $=3$ (in Arabic; accessed August 2012). 3.

Both pro-regime and revolutionary social networking sites users have stoked some vitriolic and, in some cases, dangerously sectarian discussion strands on Facebook groups. See for example a posting which lists the names of doctors accused of killing protesters admitted into hospital in Homs, together with the comments strand. See: https://www.facebook.com/photo. php?fbid $=10150588031215727 \&$ set $=t .905090$ 606\&type $=3$ (in Arabic; accessed August 2012). 4.

See: http://www.al-akhbar.com/node/18516 (in Arabic; accessed December 2012) 5.

The research methodology is somewhat contested, with differing interpretations on what constitutes public (and therefore freely citable) and private when posting content online. In sum researchers should err on the side of caution to avoid ethical and legal piffalls. Kozinets (2011) summarizes the main arguments well.

6.

This video was posted on Facebook by Syrian activists and can be accessed on YouTube at: http://www.youtube.com/watch?v=xS-Hgkapxc laccessed August 2012).

7.

The author is grateful to Dr Rupert Read for introducing her to this literature.
8.

See the report posted on YouTube on 17 September 2011 (in Arabic) at: http://www. youtube.com/watch? $v=$ rGZgZpL3gNI (accessed September 2011) and other clips at: http://www. youtube.com $/$ watch? $v=U c 0 Q 16 Q f n 9 k \& f e a t u r e=p$ ayer_embedded (accessed September 2011).

Definitions can vary slightly, refer to specific reports. It should be noted that the data includes GCC countries such as the UAE and Qatar, which include majority expatriate communities. The Dubai School of Government's (201 la) report 'analyzes data on Twitter and Facebook users in all 22 Arab countries, in addition to Iran and Israel'. Its May 2011 report $(2011 \mathrm{~b}$ ) includes data from Turkey as well.

\section{0.}

For a summary and update of the statistics see: http://www.arabsocialmediareport.com/ Facebook/LineChart.aspx?\&PriMenuID $=18 \&$ Cat $\mathrm{D}=24 \&$ mnu=Cat (accessed August 2012)

11.

For more information see: http://www.treasury. gov/resource-center/sanctions/Programs/ pages/syria.aspx (accessed August 2012).

A look at Google data from 2010 to December 2011 further illustrates the rise in use of Google and access to YouTube from February to June 2011 , with a drop from June 2011 onwards (presumably due to deeper electricity and telecommunications cuts): http://www.google. $\mathrm{com} /$ transparencyreport/traffic/? $\mathrm{r}=\mathrm{SY} \& \mathrm{l}=$ YOUTUB E\&csd $=1295947800000 \&$ ced $=1298367000000$ (accessed December 2011).

13.

This page was accessed via a Facebook account at www.facebook.com/kollana. shabbeha (accessed August 2012) but it was removed before the publication of this article.$$
14 .
$$

This page can still be accessed via: https:// www.facebook.com/hamza.alshaheed (accessed August 2012)

15.

The Facebook group is available at: https:// www. facebook.com/syrian. hurriyat? sk=info (accessed August 2012).
16.

The article and video clip can be viewed at: http:/ tinyurl.com/74t24ph (accessed August 2012).

17.

Not active by the time of publication; not to be confused with the Egyptian publication of the same name.

\section{8.}

There have been changes in accessing the content and http://souriatna.wordpress.com has access to earlier publications while latest editions are availab via issuu.com/souriatna/docs and at https://

facebook.com/souriatna (accessed August 2012).

19.

See: www.syrianswa.org (accessed August 2012)

20.

See: https://www.facebook.com/ShaamNews (accessed August 2012).

21.

See https://www.facebook.com/UgaritNEWS

(accessed August 2012).

22.

Available at https://www.facebook.com/LCCSy (accessed August 2012).

23.

Access via https://www facebook com/

7omsrevolution?sk=info (accessed August 2012)

24.

Group information at hitps://www.facebook.com/

DaraaCoordination (accessed August 2012)

25.

See this round-up, which discusses activists planning for strikes and the dangers from security monitoring their social networks, published on Aljazeera.net: http://tinyurl.com/d35+25n (accessed December 2011).

26.

Hosted on YouTube at: http://www.youtube. $\mathrm{com} /$ watch $v_{\mathrm{v}}=\mathrm{mAW}$ vyllhQ1 $\mathrm{g} \&$ noredirect $=1$ (accessed August 2012).

There is a pro-revolutionary Facebook group called Syria's Silent Majority, https://www.facebook. com/SyriaSilentMajority (accessed August 2012).

\section{8.}

The Facebook group is at: https://www. facebook. com/Midan.Revolution (accessed August 2012).

\section{9.}

programme has been posted on YouTube: http://www.youtube.com/

watch? $v=$ chSl5pQdG3s (accessed August 2012).

30.

Footage available at: http://www.youtube.com/ watch?v=4hC6II 1 EajY (accessed August 2012)

31.

See the image (red balloons with the word irhal, which means 'Go!' or 'Step down!') from Idlib

at: http://tinyurl.com/7+9ttgy (originally posted on 6 November on the Facebook site E.N.N.; accessed August 2012).

\section{2.}

Posted on YouTube at: http://www.youtube.com/ watch?feature=player_embedded\&v=izLhLPjNonk (accessed August 2012).

33.

See footage at: http://www.youtube.com/ watch ? $_{\mathrm{v}}=\mathrm{CHgMY} 85 \mathrm{leEO}$ (accessed August 2012). These strikes have been called since at least October 2011, gaining common ground and media coverage by the end of the year as 'dignity strikes', which resulted in security forces attacking any shops that observed the strikes.

34.

The Facebook group is at: https://www. facebook.com/TheSyrianlibrary laccessed August 2012).

35.

The site now has a website at: http://www.freesyrians.net (accessed August 2012)

36.

Available at: https://www.facebook.com/Free. Syrian.Intellectuals (accessed August 2012).

37.

A good example is the Facebook group for the satellite TV channel addounia, at: https://www. facebook.com/addounia.channel (accessed August 2012) 


\section{REFERENCES}

ABU-ASSALI S (2011) Going underground. Syria Today, October. Available at: http://www.syria-today.com/index.php/life/16606-going-underground (accessed October 2011).

ALLAF R (2011) Syria's pre-Assad past could be assuring omen for its future. 27 November. Available at: http://www.guardian.co.uk/commentisfree/2011/nov/27/ syria-without-assad-good-omen?newsfeed=true (accessed November 2011).

AL-ZU'BI O (2011) Where are the Syrian elites?' al-Quds al-Arabi newspaper (in Arabic), 14 November.

AOURAGH M (2011) Palestine Online: Transnationalism, the Internet and the Construction of Identity. London: I.B. Tauris.

AOURAGH M and Alexander A (2011) The Egyptian experience: sense and nonsense of the internet revolution. International Journal of Communication 5: 1344-1358.

ARENDT H (2006 [1963]) On Revolution, with an introduction by Jonathan Schell. London: Penguin.

ATASSI MA (2011) My Syria awake again after 40 years. New York Times Online, 26 June. Available at: http://www.nytimes.com/201 1/06/27/ opinion/27 Atassi.html?pagewanted=18_r= 1 (accessed June 2011)

BARNEY W and GRIMES J (1997) Counterhegemonic discourses and the internet. Geographic Review 87(2): 159-274.

BEININ J (2001) Workers and Peasants in the Modern Middle East. Cambridge: Cambridge University Press.

BURRIS G (2011) Lawrence of e-rabia: Facebook and the new Arab Revolution. Available at: http://www.jadaliyya.com/pages/index/2884/lawrence-ofe-rabia_facebook-and-the-new-arab-revo (accessed October 2011).

COLE J (2011) Television, Twitter, Facebook and the Libya revolution. Available at http://www.juancole.com/201 1/08/tv-twitter-facebook-and-the-libyanrevolution.html (accessed September 2011).

COOKE M (2007) Dissident Syria: Making Oppositional Arts Official. Durham, NC: Duke University Press.

DICK M (2006) The thin red lines: censorship controversy, and the case of the Syrian soap opera Behind Bars. Available at: http://www.tbsjournal.com/Dick.html (accessed September 2009).
DICK M (2007) Syria under the spotlight: television satire that is revolutionary in form, reformist in content. Available at: http://www.arabmediasociety. com/?article=419 (accessed December 2011).

DOWNING J (2001) Radical Media: Rebellious Communication and Social Movements. Thousand Oaks, CA: Sage.

DUBAI SCHOOL OF GOVERNMENT (201 la) Arab Social Media Report, Facebook Usage Factors and Analysis. Dubai School of Government 1 (1), January, Dubai: Dubai School of Government.

DUBAI SCHOOL OF GOVERNMENT (201 lb) Arab Social Media Report, Civil Movements: The Impact of Facebook and Twitter. Dubai School of Government 1 (2), May, Dubai: Dubai School of Government.

DURHAM MG and KELLNER D (eds) (2006) Media and Cultural Studies: Keyworks, revised edn. Oxford: Blackwell

EID G (2004) The internet in the Arab world: a new space for repression? Available at: http://www.anhri.net/en/reports/net2004/syria.shtml (accessed November 2011).

GAUNTLETT D (1996) Ten things wrong with the media 'effects' model. Available at http://www.theory.org.uk/david/effects.htm (accessed January 2012).

HADDAD B (2012) Business Networks in Syria: The Political Economy of Authoritarian Resilience. Stanford,CA: Stanford University Press.

HANANO A (2011) A Syrian president's daughter. 6 December. Available at http:// www.jadaliyya.com/pages/index/3396/a-syrian-presidents-daughter hana-choucri-al-kouat (accessed December 2011).

HARKIN J (2009) A Reappraisal of the Practice of Contemporary Journalism in Syria, MPhil. thesis, Oxford University.

HARKIN J, Anderson K, Morgan L and Smith B (2012) Deciphering User-generated Content in Transition Societies: A Syria Coverage Case Study. Washington, DC: Center for Global Communication Studies, Annenberg School for Communication, Internews Center for Innovation and Learning.

HEYDERMANN S (2004) Networks of Privilege in the Middle East. New York: Palgrave Macmillan. 
HIJJAWI A (2011) The role of Al-Jazeera (Arabic) in the Arab revolts of 2011. In: People's Power: The Arab World in Revolt: Political Analysis and Commentary from the Middle East, 2 April. Special Issue, Heinrich B II Stiffung. Available at: http:// www.ps.boell.org/downloads/Perspectives_02-10_Aref_Hiijiawi1.pdf HINE C (ed.) (2010) Virtual Methods: Issues in Social Research on the Internet. Oxford: Berg.

HOWARD P, Duffy A, Freelon D, Hussain M, Mari W and Mazaid M (2011) Opening Closed Regimes: What Was the Role of Social Media during the Arab Spring? Working Paper, Project on Information Technology and Political Islam, University of Washington, Seattle.

HUMAN RIGHTS WATCH (2011) Syria: rein in security services. Available at: http:// www.hrw.org/news/2011/04/21/syria-rein-security-services (accessed October 2011).

ISMAIL S (2009) Changing social structure, shifting alliances and authoritarianism in Syria. In: Lawson FS (ed.) Demystifying Syria. SOAS Middle East Issues series. London: Saqi, pp. 29-56.

KASSAB D and Lane E (2011) The digital divide. Syria Today, June. Available online at http://www.syria-today.com/index.php/june-2011/815-focus/15215the-digital-divide, (accessed December 2011).

KAWAKIBI S (2010) The Private Media in Syria. Working Paper, University of Amsterdam and HIVOS.

KOZINETS RV (2011) Netnography: Doing Ethnographic Research Online. London: Sage. LAWSON G (2011) Halliday's revenge: revolution and international relations. International Affairs 87(5): 1067-1085.

LOTAN G et al. (2011) The revolutions were tweeted: information flows during the 2011 Tunisian and Egyptian revolutions. International Journal of Communications 5 : 1373-1405.

MACMANUS R (2011) Why Twitter's 'information network' strategy is under pressure from Facebook and Google +. Available at: http://www.readwriteweb.com/ archives/twitter_information network_strategy_under_pressure.php (accessed September 2011).

MARROUCH R (2011) Broadcasting Syria's uprising. al-Akhbar (English) newspaper, 5 October. Available at: http://english.al-akhbar.com/content/omar-edelbibroadcasting-syria\%E2\%80\%99s-uprising (accessed October 2011).
PERTHES V (2004) Arab Elites: Negotiating the Politics of Change. Boulder, CO: Lynne Rienner.

PLEASANTS N (1997) Free to act otherwise? A Wittgensteinian deconstruction of the concept of agency in contemporary social and political theory. History of the Human Sciences 10(4): 1-28

PRATT N (2007) Democracy and Authoritarianism in the Arab World. Boulder, CO: Lynne Rienner.

PRESTON J (2011) Seeking to disrupt protestors, Syria cracks down on social media. New York Times online, 22 May. Available at: http://www.nytimes.com/201 1/05/23/ world/middleeast/23facebook.html (accessed August 2012).

PROVENCE M (2005) The Great Syrian Revolt and the Rise of Arab Nationalism. Austin: University of Texas Press.

RUTTER J and SMITH G (2010) Ethnographic presence in a nebulous setting. In: Hine C (ed.) Virtual Methods: Issues in Social Research on the Internet. Oxford: Berg, pp. 81-92.

SALEM F (2011) The role of media in Arab societies. Conference presentation, 14 June Zayed University, Abu Dhabi.

SHARABAJEE I (2011) 'Rumour' in Syria as a means of control. al-Hayat newspaper (in Arabic), 12 December. Available at: http://international.daralhayat.com/ internationalarticle/338302 (accessed December 2011).

SPARKS C (2010) Media and transition in Latin America. Westminster Papers in Communication and Culture 8 (2): 3-27.

SPOT ON PR/Effective Measure (2010) Media Consumption and Habits of MENA Internet Users, September. Report by Spot On PR/Effective Measure. Dubai.

TAYARA S (2011) Optimistic. Posted 29 November (in Arabic). Available via Liberal Syrians for a Free Syria Facebook page: http://tinyurl.com/cg4sj2f

UNITED NATIONS GENERAL ASSEMBLY, Human Rights Council (2011) Report of the International Independent Commission of Inquiry on the Syrian Arab Republic, 23 November. Geneva: UNGA.

VIÉNET R (1968) Enragés et situationnistes dans le mouvement des occupations. Paris: Gallimard. (Trans. Goldner L and Sieveking P, 1992, New York: Autonomedia. Available at: http://www.cddc.vt.edu/sionline/si/enrages.html). 


\section{SOCIAL MEDIA AND THE SYRIAN REVOLUTION \\ Hussein Ghrer \\ Syrian Centre for Media and Freedom of Expression}

Editors' note: Syrian blogger Hussein Ghrer wrote the first draft of this article on 14 February 2013, shortly affer he was released from his first arrest for 37 days in December 2011 . In it the writer sheds light on the role that social media have so far played in the Syrian revolution. Two days later, on 16 February 2012, Ghrer and 15 of his colleagues at the Syrian Centre for Media and Freedom of Expression (SCM) were arrested during a raid on their office by the Syrian security forces. Over a year has now passed without trial, indictment or court referral. Maurice Aaek, a friend and Syrian online journalist, added his comments as an afterword in February 2013, a year later. 